UDC: $376-054.6: 159.9$

\title{
CONGRUENCE OF STRATEGIES TO MANAGE CAUSES AND EFFECTS OF TEST ANXIETY AMONG INTERNATIONAL BACCALAUREATE STUDENTS BEFORE TAKING THEIR FINAL EXAMS
}

\author{
Danuta Główka \\ Ph.D., Institute of Applied Linguistics, \\ Jan Komen $\square$ ski Higher Vocational School, Leszno, Poland \\ ORCID: 0000-0002-4659-3150, e-mail: danuta.glowka@pwsz.edu.pl
}

\begin{abstract}
International Baccalaureate (IB) students experience test anxiety connected with taking the high stakes final exams, following the two-year Diploma Programme Courses. The aim of this paper is to investigate the congruence of the causes and effects of test anxiety with strategies to manage this anxiety among IB students before taking their final exams. Qualitative responses about test anxiety from 21 IB students were collected before their exams. Causes of anxiety, as reported by the students, had to do with peer pressure and negative self-talk before the exams. Effects of anxiety were related to physical and emotional functioning as well as cognition. Strategies for managing anxiety included a variety of physical and intellectual activities. Comparing students' reported causes and effects of anxiety with their strategies to manage it revealed little correspondence between the causes and effects of a student's test anxiety and the kinds of strategies he or she employed to manage them.
\end{abstract}

Key words: test anxiety, strategies managing test anxiety, The International Baccalaureate Diploma Programme (IBDP)

Міжнародні студенти-бакалаври відчувають тривогу, пов'язану зі складанням Випускних іспитів, після проходження дворічних дипломних курсів. Метою данного дослідження є вивчення відповідності причин $і$ наслідків тривоги зі стратегіями управління иим занепокоєнням серед студентівбакалаврів перед тим, як скласти їхні випускні іспити. Перед проведенням іспитів були зібрані відповіді 21 студента-бакалавра, які пов'язані з переживанням тривоги на Випускних іспитах. Причини тривожності, як повідомяяють студенти, пов'язані з тиском однолітків та негативні відповіді самих студентів перед іспитами. Дія тривожності пов'язана з фізичною та емоційною діяльістю студентіВ. Стратегї управління тривожністю включали різні фрізині та інтелектуальні заходи. Порівнюючи відповіді студентів щодо причин і наслідків тривоги зі стратегіями для ї управління, виявлено мало відповідності між причинами та наслідками тривожності студентіВ та тими стратегіями, які студент використовує для їі управління. 


\section{Ключові слова: тривога перед іспитами, стратегї управління тривож- ністю, Міжнародна програма отримання диплома бакалавра.}

\section{Introduction}

For many years, tests have played a prominent role in student assessment. Passing important tests is what both students and educators focus on from the early years of schooling until graduation day. As a result, test anxiety can be commonly observed among students. They can feel pressured by their inner drive to succeed, a quest for perfection or a fear of failure, especially if there are high stakes attached to the test, such as graduation or admission to prestigious universities. Experiencing test anxiety could be considered beneficial if it were to produce excitement and motivation to work hard to achieve set goals. However, research shows that this is typically not the case. Test anxiety has usually negative effects, such as causing fear, confusion, or low self-esteem [11], which often lead to poor academic performance [26]. To date, the primary impetus for investigating test anxiety has been its relationship with performance measures. Relatively little attention has been given to the causal status of test anxiety or to strategies employed by students to manage test anxiety. Therefore, there is a need to raise questions on how students deal with test anxiety and on whether the strategies they employ to cope with negative effects of test anxiety are effective. The aim of this article is to present the results of a study investigating the congruence of the causes and effects of test anxiety with the strategies to manage this anxiety among International Baccalaureate Diploma Programme (IBDP) students before taking their final exams. Qualitative responses about test anxiety from 21 IB students were collected before their final exams. Causes of anxiety, as reported by the students, had to do with peer pressure and negative self-talk before the exams. Effects of anxiety were related to physical and emotional functioning as well as cognition.

Test anxiety is a subjective emotional state encountered in evaluative situations [15; 3]. There has been wide acceptance of the view that test anxiety is not a unitary factor but a complex composed of constituents that have different characteristics. There have been two major approaches to the multifaceted perception of text anxiety: the three-dimensional approach and two-dimensional approach. The three dimensional approach is represented by Zeidner [25], who identified three components of test anxiety: cognitive test anxiety (negative thoughts and self-statements during assessments), affective test anxiety (the individual's appraisal of their physiological state), and behavioral test anxiety (avoidance and procrastination of work, poor study skills). The two dimensional approach is represented widely among researchers $[21 ; 5 ; 3]$. According to this approach, there are two components of test anxiety: affecttive test anxiety, traditionally labeled emotionality, and cognitive test anxiety, traditionnally labeled worry. Typically, the emotionality component manifests it self through physiological responses experienced before or during evaluative situations, such as feelings of panic, nausea, and increased heart rate. The worry component reflects such maladaptive cognitions as fear of failure, catastrophic expectations, feelings of inadequacy, negative self-talk, and negatively comparing oneself to others [3]. 
The main concern of researchers and educators has been to examine the differential impact of these two components of test anxiety on academic performance. Early work [4] showed that high emotionality only has a negative impact on performance when the individual also experiences high worry, suggesting that worry is the dominant predictor of performance. Data available from more recent correlational studies $[3 ; 22 ; 18]$ corroborate the early results indicating that worry exerts a significant negative influence on academic performance.

Questions about the relationship between test anxiety and performance have been raised relatively frequently in comparison with the few studies investigating the causal status of test anxiety. Measurements of test anxiety and academic performance are correlated, but there is no evidence that the two variables are causally related [17]. Some attempts have been made to examine the effect of poor study skills and negative cognition on academic performance. The results of intervention research suggest that study skills training is not effective at reducing anxiety [10]. Treatments targeting the cognitive component of test anxiety indicate that it directly interferes with achievement [9]. According to Zeidner and Putwein [17], the explanation might be that: «...it is not anxiety per se that is responsible for a negative impact on performance but how a student copes with or responds to that anxiety». This assertion follow a line of reasoning advanced by Mathews et al. [14], who theorized that test anxiety may be characterized by metacognitive beliefs and maladaptive coping styles. Consequently, a question arises as to whether the strategies employed by students to manage test anxiety are congruent with the symptoms of anxiety that they report.

Frequent testing in educational settings requires students to deal with their anxiety in a constructive way. Experience with the process of learning enables students to develop a repertoire of strategies that allow them to competently manage difficulties that arise before and during tests. Adequate coping strategies may protect students by eliminating or reducing the causal factors, or by keeping the emotional consequences within manageable bounds [27]. However, many students, when encountering significant test anxiety, either use coping strategies ineffectively, develop avoidance strategies, or become helpless in the face of it. If misused, coping strategies may aggravate rather than reduce test anxiety. Non-solving-strategies or prolonged lack of response to problems are likely to exacerbate anxiety [24]. Therefore, examining coping processes is of primary importance, as they reflect students' efforts to manage anxiety-evoking situations and ultimately influence adaptation outcomes [12].

To create a coherent framework for investigating coping strategies, theorists have developed different classifications grouping them into general categories. According to Zeidner and Matthews [27, p. 193], there are three major categories of coping strategies for managing anxiety: problem-focused coping, emotion-focused coping, and avoidance-oriented coping. Problem-focused coping refers to solving the problem either by removing or altering the anxiety-provoking situation. Although, in the case of test anxiety, eliminating the stressor (the test) is not possible, its influence can be reduced by seeking assistance in handling the situation, which can improve students' competences to manage the stressful circumstances. Emotion-focused coping is oriented towards eliminating, reducing or regulating the emotional tension. Emotion-focused 
ways of coping with anxiety include, for example, using relaxation techniques, turning to friends for emotional support, distancing oneself from the stressor, and seeing the stressor in a positive light. Avoidance-oriented coping is a mechanism developed to reduce anxiety by escaping stressful circumstances either mentally or behaviorally. These strategies can be either person-oriented (seeking or avoiding other people) or task-oriented (procrastinating or participating in non-relevant tasks). Although avoidance techniques are associated with positive outcomes for a short period of time, the long-term effects can be detrimental. Furthermore, Spanrgel et al. [20] showed that avoiding the experience of anxiety can result in a damaging increase of unconscious emotional arousal on a physiological level.

Although the above-mentioned descriptive accounts of different types of coping anxiety can prove useful in identifying the types of efforts employed by students to change their cognitive and behavioral efforts to deal with test anxiety, they cannot be prejudged as adaptive or maladaptive. As Zeidner and Matthews [27, p 196) point out: «... the concern must be for whom, and under what circumstances, a particular coping mode has adaptive consequences, rather than the wholesale categorization of coping as adaptive versus maladaptive». This assertion implies individual character of anxiety coping techniques. Specifically, a coping strategy found effective for one student may prove ineffective for other students. More definite conclusions require empirical evidence.

The International Baccalaureate Diploma Programme (IBDP) is a two-year educational programme designed for students aged 16-19. The DP curriculum is made up of:

- Six subject groups: studies in language and literature; language acquisition; individuals and societies; sciences; mathematics; the arts. Each student takes at least three (but not more than four) subjects at higher level, and the remaining at standard level.

- The DP core, comprising theory of knowledge (TOK), and creativity, activity, and service (CAS).

- The extended essay (EE).

DP assessment procedures are designed to measure students' level of mastery in advanced academic skills, such as solving problems creatively, analyzing and presenting information, and evaluating and constructing arguments. Apart from measuring achievement in academic skills, DP assessment encourages students to acquire intercultural skills. Student results are determined by their performance against set standards. The IB uses both internal and external assessment in the DP. The form of the internal assessment varies by subject. This includes: oral work in languages, fieldwork in geography, laboratory work in the sciences, investigations in mathematics, and artistic performances. Externally assessed coursework, completed by students over an extended period under teacher supervision, forms part of the assessment for the theory of knowledge (TOK) essay and the extended essay (EE). For most courses, externally assessed written examinations are given at the end of the DP ( 2 weeks in May) and they form the basis of the overall - assessment. ${ }^{1}$

${ }^{1}$ The max. total DP points score is 45 (6 subjects, each 7 points $\left.=42, \mathrm{EE}+\mathrm{TOK}=3\right)$. The min. total -24 . 
Taking into consideration the fact that IB exam scores are given significant weight in the IB Diploma Programme combined performance, the pressure to do well on the exams is inevitable. Moreover, many IB students choose prestigious Polish and foreign universities, whose admission requirements are very high. Therefore, while preparing for the exams, students may experience anxiety associated with negative consequences the exams might have for their future prospects if their score is insufficient or if they fail. Thus, test apprehension increases, often inducing negative physiological, behavioral and cognitive reactions. These assumptions find empirical evidence in the results of a descriptive study conducted at Purdue University. In the survey [7] 95 IB diploma holders were asked to reflect on their high school experiences. Generally speaking, the participants reported a beneficial role of the programme, especially in coping with the challenges of university education. However, when elaborating on negative aspects of the programme, next to «elitist atmosphere» most of them mentioned workload and exam stress.

The questions addressed in the present research are as follows:

1. What are the perceived causes and effects of anxiety among IB students?

2. What strategies do IB students employ to manage the anxiety before their final exams?

3. Are the causes and effects of test anxiety congruent with the strategies for managing it?

Participants. The subject group comprised 21 third-year high school students, aged 19, involved in a two-year IB program plus one year of pre-IB studies. The gender composition of the cohort was evenly distributed; the group consisted of 11 female students and 10 male students. While taking part in the research study, the students were preparing for their final exams.

Data collection and analyses. Students' responses were collected via questionnaire in April 2016. Students were asked to write their feelings regarding the anxiety they were going though before their final exams. They were asked to fill in a selfreport questionnaire during a weekly class meeting with their class teacher. The questionnaire included 3 questions: What are the causes of test anxiety? What are the effects of test anxiety? How do you cope with test anxiety? The data which emerged from the accounts from the open-ended questions were subjected to qualitative analysis via the constant comparison method [13] and the two level coding system (open and axial) [6] based on grounded theory. The first level of the process was open coding, which means segmenting data into units of meaning. The units were not interpreted or described, but categorized in the form of abstract, unfocused (open) concepts. During the next stage of the coding process, axial coding, categories were linked and put into groups on the basis of generic relationships [6].

Results. The multiple readings of students' responses and categorization of each meaningful word, sentence or phrase into a unit became the basis for constructing a set of recurring themes representing students' opinions about the investigated issue. The emergent categories for causes of test anxiety themes are discussed below and relevant extracts from the student accounts are presented. 
One of the most commonly mentioned causes of anxiety was the effect of the exams on future. The participants focused on the threat of poor results and negative consequences. These debilitating thoughts and concerns resulted from the fact that the students assigned considerable importance to performance in exam results IB, seeing it as a potential means of securing their future. This is evident in the following comment: like».

«If I don't get an offer from my first choice university, I will have to do things I do not

Many respondents reported the feeling of hopelessness they experienced when thinking about the exams. They worried about how anxiety would affect their performance, believed that they had no control over their performance, and worried about feeling helpless when they see the exam sheet. The following excerpts illustrate these points:

«I am afraid my mind will go blank the moment I see questions.

I know the material, but when I take the test I go blank!»

Some students perceived IB exams as difficult, which aroused their worry (cognitive anxiety). One participant wrote:

"I know it's gonna be hard, the exams are extremely demanding.»

Another cause of test anxiety often mentioned by the participants was peer pressure. Students worried about how their classmates were doing in comparison to themselves. To illustrate:

"I feel stressed when I hear the others have been revising for weeks and I haven't started yet.»

Parents' expectations constituted a considerable source of the students' anxiety. According to the responses, parents did not usually say explicitly what they were expecting, but the students felt that successful completion of the IB exams and studying at a prestigious university was how parents envisaged their children's future.

"I do not want to disappoint my parents.

I know they want me to do well on the exams.»

A few respondents mentioned the fact that not all topics from the syllabus had been covered, which added fearful thoughts to their already strong feeling of uncertainty concerning the coming exams. The following extract exemplifies the finding:

"With just one month to go, we haven't completed our mathematics syllabus, that's very bad.»

Meeting the minimum admission requirements set forth by prestigious universities and difficult exam procedures were mentioned as anxiety provoking feelings. This is visible in the following comments:

"If I don't do well, I won't get to my first choice university

What arouses my stress? Getting sufficient IB grades for university entry because good results will make it possible to get to a good university

All these documents to fill in, they scare me.»

Some participants mentioned the demotivating influence of negative past experience with tests, accompanied by fearful predictions, as in the following:

"I did not do well on the mock exam, that's discouraging and it bodes ill for the final exams.» 
«Fear appeals» used by teachers - that is, the repeated messages communicated to students over the importance and timing of IB exams - were reported as anxiety-inducing situations. Some participants recalled:

"They (teachers) say: unless you get enough points, you will not get to the university. Teachers may intend this as a motivational strategy but it often has the opposite effect.»

The reasons for anxiety most frequently mentioned in the responses were guilt, resulting from inadequate time management and negative self-talk. To illustrate:

"I feel like I've wasted too much time and now I won't be able to revise all the material. I never do well no matter how much I study

You don't know THIS? You're gonna fail

No matter what I do I will fail this exam because I am a worthless being that only uses up oxygen.»

As regards the effects of anxiety reported by the participants, only one of them saw anxiety as a positive feeling, which motivated them to study hard and considerably improved their concentration. Four respondents viewed test anxiety as both a positive and negative experience. The remaining sixteen students saw only negative effects of test anxiety. The negative symptoms described by the respondents were grouped into three categories: emotional, cognitive, and physical. Among emotional effects of test anxiety were: feeling worthless, hopeless and helpless; feeling low and lost; being pessimistic, irritable and frantic; giving in to guilt. The participants' cognitive functioning was not effective when they felt anxious due to recurrent difficulty in concentrating or remembering the material. The physical effects of test anxiety mentioned in students' responses included: stomach ache; headache; rapid heartbeat; trembling; crying; problems with digestive system; panic attacks; sleep disturbances (difficulty sleeping at night, feeling sleepy when studying); fits of laughter; excessive sweating.

To analyze the congruence of students' strategies to manage their test anxiety, the reported strategies were compared with research-informed anxiety reducing strategies $[2 ; 27]$. As evidenced in Table 1 , most respondents used a range of emotionfocused strategies to cope with causes and effects of their test anxiety. Rather than addressing the stressor actively, they engaged in activities that modified their perception of the exam. Such activities as, for example, envisaging something nice or not thinking about school were mentioned to cope with perceived time constraints for the study and difficulty in meeting the minimum university admission requirements. According to Cassady [2], some proactive strategies would be more effective when coping with negative perception of the coming event. These could include, for example, making an organized study schedule or reading carefully guides for IB students applying to universities. Emotion-focused strategies (e.g. developing positive attitude playing computer games, watching favorite movies) were also used by the participants to channel negative physiological symptoms, such as stomach ache, headache, rapid heart beating, crying problems, sleep disturbances or panic attacks. None of the respondents reported asking care providers (e.g. parents, school counselors, family doctors) for help while coping with these problems. Similarly, no attempts to seek professional help were reported when coping with negative 
thoughts and depreciating self-statements. Problem-solving strategies, viewed as most adaptive in academic settings [2], were rarely mentioned in the reports. Only two students wrote that when faced with anxiety, they decided to change their study habits and work hard.

\section{Comparison of anxiety reducing strategies reported by students with research-informed anxiety reducing strategies}

\begin{tabular}{|c|c|c|}
\hline Causes/effects & Reported strategies & Research-informed strategies \\
\hline $\begin{array}{l}\text { - Perceived time } \\
\text { constraints for the study. }\end{array}$ & $\begin{array}{l}\text { - Talk to a classmate. } \\
\text { - Envisage something } \\
\text { nice. }\end{array}$ & $\begin{array}{l}\text { + Make an organized study } \\
\text { schedule and stick to it. }\end{array}$ \\
\hline - Inability to concentrate. & $\begin{array}{l}\text { - Watch favorite movies. } \\
\text { - Read books. }\end{array}$ & $\begin{array}{l}\text { + Use concentration } \\
\text { improving techniques, e.g.: } \\
\text { writing out the thoughts you } \\
\text { do have. }\end{array}$ \\
\hline $\begin{array}{l}\text { - Peer pressure - } \\
\text { worrying about how } \\
\text { other students are doing } \\
\text { in comparison to } \\
\text { yourself. }\end{array}$ & $\begin{array}{l}\text { - Read books. } \\
\text { - Play computer games. } \\
\text { - Think about } \\
\text { something nice }\end{array}$ & $\begin{array}{l}+ \text { Avoid it. Try to avoid bad } \\
\text { peer pressure by avoiding } \\
\text { friends who fuel your } \\
\text { anxiety. }\end{array}$ \\
\hline $\begin{array}{l}\text { - Meeting the minimum } \\
\text { admission requirements } \\
\text { set forth by prestigious } \\
\text { universities - sufficient } \\
\text { grades for entry. }\end{array}$ & $\begin{array}{l}\text { - Do not think about } \\
\text { school. } \\
\text { - Change study habits. } \\
\text { - Study a lot. } \\
\text { - Rest a lot. } \\
\text { - Sleep a lot. }\end{array}$ & $\begin{array}{l}\text { + Read carefully guides for IB } \\
\text { students applying to } \\
\text { Universities. } \\
\text { + Look for alternatives. } \\
\text { + Make Plan B. }\end{array}$ \\
\hline $\begin{array}{l}\text { - Stomach ache, } \\
\text { headache, rapid heart- } \\
\text { beat, trembling, crying } \\
\text { problems with digestive } \\
\text { system, panic attacks, } \\
\text { sleep disturbances (diffi- } \\
\text { culty in sleeping at } \\
\text { night, feeling sleepy } \\
\text { when studying), fits of } \\
\text { laughter, excessive } \\
\text { sweating. }\end{array}$ & $\begin{array}{l}\text { - Try to develop positive } \\
\text { attitude. } \\
\text { - Sleep and rest a lot. } \\
\text { - Drink tea. } \\
\text { - Meet friends. } \\
\text { - Listen to music. }\end{array}$ & $\begin{array}{l}\text { + Ask your care provider (e.g. } \\
\text { parent, school counselor, } \\
\text { family doctor) for advice. } \\
+ \text { See a mental health } \\
\text { provider. }\end{array}$ \\
\hline
\end{tabular}




\begin{tabular}{|l|l|l|}
\hline $\begin{array}{l}\text { - Negative self-talk: } \\
\text { negative thoughts and } \\
\begin{array}{l}\text { depreciating self- } \\
\text { statements. }\end{array}\end{array}$ & $\begin{array}{l}\text { - I do not know how to } \\
\text { manage it. }\end{array}$ & $\begin{array}{l}\text { + Try to dispute negative } \\
\text { thinking: ask challenging }\end{array}$ \\
& - I can't cope with it. & questions concerning, e.g. \\
& reality testing (e.g. What is \\
& my evidence for and against \\
& my thinking?). \\
& + Look for alternative \\
& explanations (e.g. Are there \\
& any other ways that I could \\
& look at this situation?). \\
& + Use goal-directed thinking \\
& (e.g. Is this way of thinking \\
& helping me to achieve my \\
& goals?). \\
\hline
\end{tabular}

The results demonstrate that students came up with a list of strategies to manage stress rather than one well thought-out strategy. To manage anxiety, most respondents adopted strategies that are incongruent with the causes and effects they reported. The findings corroborate a recent study conducted among medical students by Encandela et al. [8] preparing for Step 1 of the United States medical Licensing Examination, in which the comparison of individuals' strategies with causes and effects showed substantial incongruence between the selected types of strategies and the reported causes and effects of test anxiety. The results from this study also show that most participants adopted emotion-focused strategies to manage test anxiety. According to Cassady [2], these strategies can be effective in reducing the immediate threat imposed by the perceived stressor, which diminishes the short-term negative effects. As a result, students who use these strategies when coping with academic anxiety tend to show short-term adaptability to the threatening academic situation. However, in the long run these students run the risk of exhibiting lower levels of self-concept and higher level of academic anxiety. Cassady [2] argues that when the emotion-coping strategies are accompanied by the problem-solving strategies, they are effective in lowering negative emotional reactions immediately before the test. The results from this investigation provide important information regarding the fact that despite being aware of causes and effects of their test anxiety, none of the participants reported seeking from a counselor or psychologist. This might suggest that, rather than having resources leading to evidence-based approaches to manage test anxiety, the students were left to their own devices. Research shows [1] that inadequate management of test apprehension in the long run may lead to chronic anxiety, which may result in severe health problems.

The inconsistency between reported causes and effects of anxiety might be dealt with by offering scheduled guidance and support provided by school counselors or mental care specialists. Professionals could identify students' inefficient approaches to test anxiety and introduce students to strategies which best address 
individual causes and effects of anxiety. They could also replace a list of strategies reported by the students by an evidence-based strategy to deal with the most debilitating effects of anxiety. This way, students can save energy to prepare for the exam instead of expending too much energy and resources on managing anxiety.

Strategies for managing test anxiety cannot be prejudged as adaptive or maladaptive. The concern must be for whom, and under what circumstances, a particular coping strategy has adaptive consequences. This implies that anxiety-managing strategies are individualistic [27].

Although exam performances were not available for the study, and no conclusions regarding the relationship between of the strategies to manage test anxiety used by the participants and the results of the final exams can be drawn, it is reasonable to extrapolate from the obtained results that inadequate choice of strategies to cope with test anxiety might negatively influence exam results. Therefore, the conclusions of this study may constitute the basis for formulating the following research question for a further study: «Is there a relationship between the choice of strategies to manage test anxiety and subsequent test performance?»

\section{References:}

1. Baum, A. and Donna, M. Posluszny (1999). «Health psychology: mapping bio-behavioral contributions to health and illness». Annual Review of Psychology, vol. 50: 137-163.

2. Cassady, Jerrell. C. (2010). Anxiety in Schools: The Causes, Consequences and Solutions for Academic Anxieties. New York: Peter Lang.

3. Cassady Jerrell, C and Ronald. E. Johnson. (2002). Cognitive test anxiety and academic performance. Contemporary Educational Psychology, vol. 27, 270-295.

4. Deffenbacher, Jerry. L. (1986). Cognitive and physiological components of test anxiety in real life exams. Cognitive Therapy and Research, 10, 635-644.

5. Doirnyei, Zoltan. (2005). The psychology of the language learner. Individual differences in second language acquisition. New York: Routledge.

6. Dörnyei, Zoltan. (2009). Research methods in applied linguistics. Oxford: Oxford University Press.

7. Duevel, L. M. (1999). The International Baccalaureate experience: University perseverance, attainment, and perspectives on the process (Doctoral dissertation). Purdue University, Indiana.

8. Encandela, John, Crystal Gibson, Nancy Angoff, Gary Leydon, and Michael Green. (2014). «Characteristics of test anxiety among medical students and congruence of strategies to address it». Medical Education online, vol. 19. Available at: https://www.ncbi.nlm.nih.gov/pmc/articles/PMC4134671.

9. Ergene, Tunkay. (2003). "Effective interventions on test anxiety reduction». School Psychology International, vol. 24: 313-328.

10. Eysenck, Michael W.; Derakshan, Nazanin; Santos, Rita; Calvo, Manuel G. (2007). «Anxiety and cognitive performance: attentional control theory». Emotion, vol. 7: 336-353.

11. Kalisch, Raffael, Katia Weich, Hugo D. Critchley, Ben Seymour, John P. O'Doherty, David A. Oakley, Philip Allen, and Raymond J. Dolan. (2005). "Anxiety Reduction through Detachment: Subjective, Physiological, and Neural Effects», Journal of Cognitive Neuroscience, vol. 17: 874-883.

12. Lazarus, Richard S. and Susan Folkman. (1984). Stress, appraisal, and coping. New York: Springer.

13. Lincoln, Yvonne S. and Egon G. Guba. (1985). Naturalistic Enquiry. Newbury Park, Calif.: Sage.

14. Matthews, Gerald, Emma J. Hillyard, Sian E. Campbell. (1999). «Metacognition and maladaptive coping as components of test anxiety». Clinical Psychology and Psychotherapy, vol. 6: 111-125.

15. McDonald, Angus S. (2001). "The Prevalence and Effects of Test Anxiety in School Children», Educational Psychology, vol. 21: 89-101.

16. MacIntyre, Peter D and Robert Gardner. (1991). «Language anxiety: its relationship to other anxieties and to processing in native and second language», Language Learning 41: 513-534. 
17. Putwein, David. (2008). «Examination stress and test anxiety». The psychologist, vol. 21: 1026-1029. Available at: https://thepsychologist.bps.org.uk/volume-21/edition-12/examination-stress-and-test-anxie ty (access: Nov. 2016).

18. Putwein David, $W$ and Natalie Best. (2011). «Fear appeals in the primary classroom: effects on test anxiety and test grades», Learning and Individual differences 21: 580-584.

19. Schutz, Paul A. and Reinchard Pekrun R. (eds.). (2007). Emotion in education, San Diego: Elsevier.

20. Spangler, G., Pekrun, R., Kramer, K., E Hofmann, H. (2002). «Students' emotions, physiological reactions, and coping in academic exams». Anxiety, Stress \& Coping: An International Journal, vol. 15: 413-432.

21. Spielberger, Charles. D and Peter R. Vagg. (1995). Test Anxiety: Theory, Assessment, and Treatment. The Series in Clinical and Community Psychology. Washington DC: Taylor and Francis.

22. Vitasari, Prima, Abdul Wahab, M. N., Othman, A., Herawan, T., and Sinnadurai, S. K. (2010). «The Relationship between Study Anxiety and Academic Performance among Engineering Students». Procedia Social and Behavioral Sciences, vol. 8: 490-497.

23. Vitasari, P., Nubli M., Waahab, A. and others (2011). A pilot study of pre- post anxiety treatment to improve academic performance for engineering students. Procedia-Social and Behavioral Sciences. Available at: http://ac.els-cdn.com/S1877042811009268/1-s2.0-S1877042811009268-main.pdf?_tid=7 cccd098-a353-11e6-be7a-00000aab0f27Eacdnat $=1478349145 \_e 8 e 2 c a 8 c b 2625$ ef9e8d1f6b0c7170515 (access November 2016)

24. Wells, Adrian. (2000). Emotional disorders and metacognition: innovative cognitive therapy. New York: John Wiley \& Sons.

25. Zeidner, Moshe. (1988). Test anxiety. The state of the art. New York: Plenum.

26. Zeidner, Moshe. (2007). «Text anxiety in educational contexts: Concepts, findings and future direction», in: Paul A. Schutz and Reinchard Pekrun R. (eds.), Emotion in education, San Diedo: Elsevier, 165-184.

27. Zeidner Moshe and Gerald Matthews. (2011). Anxiety 101. New York: Springer Publishing Company.

Received: April, 5

Accepted: May, 20 